\title{
Józef Kąś
}

Uniwersytet Jagielloński

Katedra Historii Języka i Dialektologii

ORCID: 0000-0003-1519-6088; e-mail: jozef.kas@uj.edu.pl

\section{Ikonografia w słowniku gwarowym}

\begin{abstract}
Abstrakt: W związku z szybkim zanikaniem wiejskiej kultury materialnej opisy językowe artefaktów stają się coraz trudniejsze. Istotnym elementem dopełniającym takie opisy staje się w tej sytuacji ikonografia. Ikonografia jest więc w słowniku gwarowym:

1) dopełnieniem definicji;

2) szansą weryfikacji definicji;

3) pomocą w poprawnym ustawieniu ekspozycji etnograficznych;

4) środkiem przedstawienia specyfiki etnograficznej w danym regionie;

5) uzupełnieniem opisu etnologicznego;

6) środkiem przedstawienia relacji między elementami składowymi artefaktu złożonego konstrukcyjnie.
\end{abstract}

Słowa kluczowe: słownik gwarowy, ikonografia, gwara podhalańska
Abstract: Iconography in a dialect dictionary. The rapid disappearance of rural material culture ren- ders linguistic description of artifacts increasingly difficult. In this situation, iconography has become an important element complementing these descriptions. In a dialect dictionary, iconography
1) complements the description;
2) offers an opportunity to verify the definition;
3) helps to correctly orient ethnographic exposition;
4) acts as a vehicle for the presentation of the ethnographic specificity in a region;
5) supplements the ethnological description;
6) is a means of presenting the relations between the constituent parts of a structurally complex artifact.

Keywords: dialect dictionary, iconography, Podhale dialect.

Podjęcie w niniejszym artykule rozważań na temat tytułowego problemu może się wydawać czymś mało istotnym, wręcz truizmem. Wszak rysunki, zdjęcia są obecne w różnorakich publikacjach od dawna. Ze słowników gwarowych przytoczyć można choćby Porównawczy słownik trzech wsi małopolskich Mariana Kucały (1957). W tym kontekście warto też przypomnieć słownik Henryka Josta, poświęcony terminologii technicznej na Podtatrzu (Jost 1987). Co zatem zmieniło się w opisywanej rzeczywistości pozajęzykowej, że problem staje się tak ważki? Można powiedzieć, że nie stało się nic takiego, co nie byłoby znane już dawniej. Chodzi natomiast o skalę i tempo zjawisk. Owe zjawiska to przemiany cywilizacyjne, społeczne i językowe w środowiskach wiejskich w okresie powojennym, a w szczególności w okresie ostatnich dwóch pokoleń, tj. w przybliżeniu 50 lat. Elektryfikacja spowodowała zastąpienie pracy 
ręcznej pracą zmechanizowaną, a to pociągnęło za sobą zarzucenie ręcznych narzędzi pracy i wprowadzenie maszyn. Zmiany takie pociągają za sobą zanik artefaktów i nazewnictwa. W zakresie zmian społecznych istotne było podniesienie poziomu wykształcenia, walka z analfabetyzmem, a wreszcie - powstanie „,nowej inteligencji” w procesie tzw. ,awansu społecznego”. Sygnalizowaną tu atmosferę lat powojennych znajdujemy choćby w powieści Juliana Kawalca (1964) Tańczący jastrząb.

$\mathrm{Na}$ tle tych zmian należy sytuować słownik gwarowy, który mógłby sprostać wymaganiom wynikającym $\mathrm{z}$ tych przeobrażeń. O metodologicznych założeniach takiego słownika pisałem w innym artykule (Kąś 2017). W tym miejscu przypomnijmy w skrócie ich istotę. Wskazywane przemiany na powojennej wsi doprowadziły do zmiany charakteru relacji między trzema najistotniejszymi postaciami: autorem, informatorem oraz czytelnikiem. Zburzona została wspólnota kulturowo-językowa między informatorem, autorem i czytelnikiem słownika gwarowego. Wiedza współczesnego informatora gwarowego jest ograniczona w porównaniu z wiedzą kulturowo-językową jego poprzednika. Dawniejszy informator był kontynuatorem kultury duchowej i materialnej swego dziadka. Z kolei jego wnuk już niekoniecznie. Współczesne pokolenie młodych autorów słowników gwarowych nierzadko nie ma już tradycyjnego doświadczenia kulturowego wyniesionego z domu rodzinnego, co skutkuje niekiedy niepełnymi lub wręcz błędnymi definicjami obcych im pojęć gwarowych. Trzecią postacią, marginalizowaną w tradycyjnym słownikarstwie gwarowym, jest odbiorca. Określenie „tradycyjne słownikarstwo gwarowe" odnoszę do metodologicznych i praktycznych aspektów leksykografii gwarowej sprzed 50 lat, tj. sprzed dwóch pokoleń. Odbiorcą takiego słownika bywał zwykle inny językoznawca - dialektolog lub historyk języka. Tymczasem współcześnie obok tradycyjnego czytelnika pojawił się czytelnik nowego typu - zainteresowany dawniejszą kulturą wiejską, ale niemający często wykształcenia językoznawczego, umożliwiającego odbiór tak specyficznego dzieła, jakim jest słownik gwarowy. Dziś po słownik gwarowy sięgają nie tylko osoby dorosłe, ale też młodzież szkolna.

Współczesny słownik gwarowy musi być zatem oparty na założeniach metodologicznych umożliwiających rzetelny i fachowy opis zmieniającej się rzeczywistości, musi też sprostać wymaganiom bardzo zróżnicowanego czytelnika. Autor niniejszego artykułu jest przekonany, że hasło gwarowe nie może być przedstawiane tylko w kontekście wyrazowym, czyli gramatycznym i leksykalnym; winna to być prezentacja w kontekście kulturowym. Leksem jest bowiem odbierany całościowo. Do tego potrzebna jest zarówno ilustracja tekstowa, jak i ikonograficzna. Stąd też wypływa istotna konstatacja odnosząca się do obecności ilustracji ikonograficznej we współczesnym słowniku gwarowym: nie służy ona upiększeniu, uatrakcyjnieniu tekstu słownika. Jest elementem opisu semantycznego, równie ważnym co tekst, a nierzadko ten tekst przewyższającym z informacyjnego punktu widzenia. Do zdjęć, rysunków należy dodać filmy, a nawet elementy dźwiękowe. Dla uproszczenia będziemy się dalej posługiwać pojęciem ,ikonografii”.

Rozpatrzmy zatem funkcje ikonografii we współczesnym słowniku gwarowym.

Ilustracja jako dopelnienie definicji. To przypadek, kiedy czytelnik nie zna desygnatu, a sama definicja nie jest w stanie objąć wszystkich detali, ich kształtu, wielkości, koloru, przystawalności elementów względem siebie itd. Potrzebę takiego właśnie uzupełniania definicji dostrzegał już M. Kucała, który we wspomnianym słowniku 
przedstawia rysunki sprzętów i narzędzi rolniczych i domowych, mimo iż 60-70 lat temu narzędzia te były powszechnie znane. Taka refleksja winna towarzyszyć słownikarstwu współczesnemu, kiedy tempo zanikania artefaktów tradycyjnej kultury wiejskiej gwałtownie przyspieszyło. Niejednokrotnie słyszałem uwagę, że ilustracje w słoniku gwarowym nie są konieczne, bo przecież istnieją muzea etnograficzne, skanseny, izby pamięci itp. Odpowiedź w takim przypadku jest jedna: wskazane instytucje gromadzą zaledwie cząstkę elementów wiejskiej kultury materialnej; znacznie więcej znajduje się na strychach, w komorach itp. Do czasu aż młody gospodarz nie zaprowadzi na takim strychu porządku! Niestety, stare przedmioty są postrzegane często jako symbole biedy i zacofania.

Ilustracyjnie winne być przedstawiane zresztą nie tylko artefakty dawnej kultury. Ileż to przedmiotów codziennego użytku, modnych jeszcze 10-15 lat temu, dziś pozostaje w zapomnieniu. Maszyny rolnicze, nie tylko te wyrabiane przez dziadów, ale też niedawno kupione w sklepach, rdzewieją, bo kupowane są coraz nowsze, wydajniejsze, praktyczniejsze. Nie należy też przy tym zapominać, że słownik tworzony bywa nie tylko dla czytelnika współczesnego, ale też dla tego, który przyjdzie po nas choćby za 50 lat. Opis dawniejszych, a nawet dzisiejszych przedmiotów winien być zatem uzupełniony, poszerzony o ilustracje.

Problem ilustrują poniższe przykłady:

JARZMO: 'drewniana konstrukcja, będąca odpowiednikiem końskiego chomąta, zakładana na kark wołom lub krowom, mocowana do dyszla' (Kąś 2017, IV, 232).

Kolejny przedmiot jest bardziej złożony i rzadziej spotykany. To GRABKI: 'przyrząd o dwóch, trzech lub czterech długich zębach, osadzonych w SLUPKU' ${ }^{1}$ poprzecznie przypiętym do kosy (za pomocą MOTYCKI wciśniętej pod PIESTRZYŃ); drugi koniec SŁUPKA połączony jest z pałąkiem przymocowanym z kolei do KOSISKA. Grabki umożliwiają w czasie koszenia równe układanie wysokiego zboża na pokos' (Kąś 2016, III, 443). Bardzo znamienna jest w tym przypadku wypowiedź, w której informatorka stara się opisać ten przyrząd, zakończona dramatycznym okrzykiem potwierdzającym konieczność wizualnego przedstawienia przedmiotu: $O$ matko! To trza widzieć!

Grabki: stupek z motyckom (kawołek drewiynka kwadratowego z metalowom motyckom na kóńcu), w nim zymby trzi jasiyniowe, motycke sie wbijo do pierściynia. Nizyj stupka jes grzondka przitwierdzono do kosiska (wywiertano dziurka i wbito). Od grzondki do kozdego zymba idom skryncone dróciki, to som toty procki. Trzeba strzelić okiym na prynt (pront), cy zymby idom równiućko. Jak trza, to sie przikrynco tymi prockami. Od stupka idzie obłoncek przimocowany do kosiska. O matko! To trza widzieć! (Podhale, Raba Wyżna).

Ilustracja jako weryfikacja definicji. Zdarza się, że w słowniku gwarowym pojawia się definicja nie do końca prawdziwa. Tak dzieje się zwykle, kiedy autor definicji

\footnotetext{
1 Wyrazy pisane wersalikami w obrębie definicji są hasłami w słowniku. Takie rozwiązanie techniczne stosowałem w Słowniku gwary orawskiej (Kąś 2003; 2011) oraz w Ilustrowanym leksykonie gwary i kultury podhalańskiej (Kąś 2015-2019).
} 


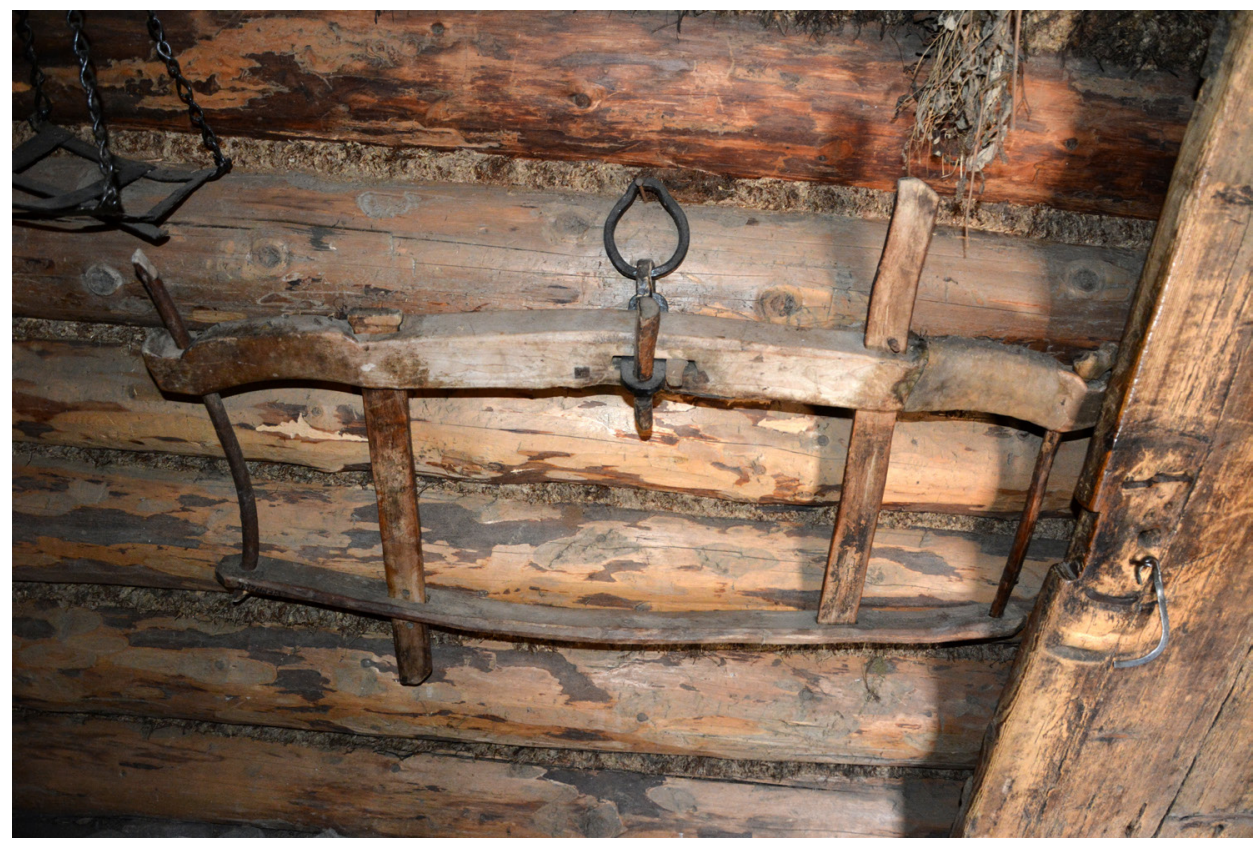

Fot. 1. Jarzmo

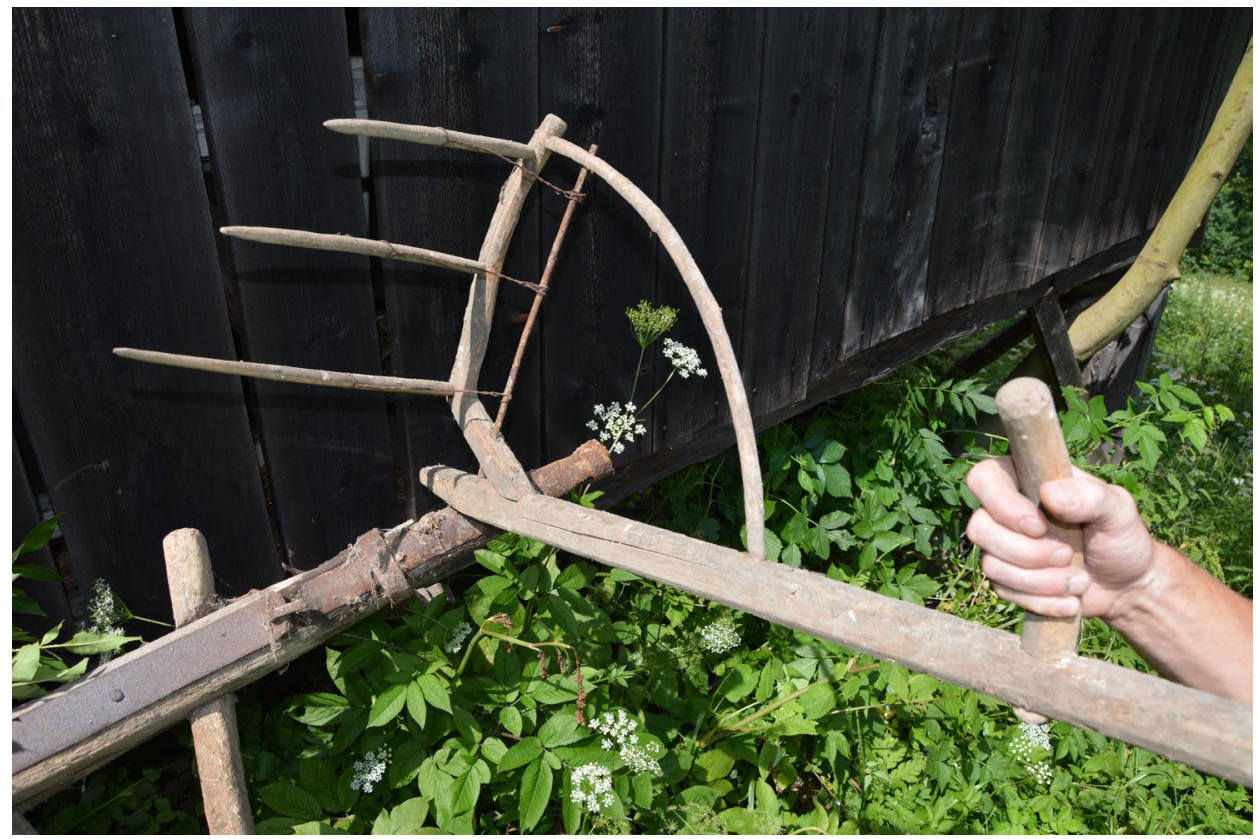

Fot. 2. Grabki 
nie widział opisywanego przedmiotu lub użył niewłaściwych słów. A oto przykład: w regionalnym, nieprofesjonalnym Małym słowniku gwary góralskiej z Rycerki Górnej (na południu Żywiecczyzny), autorstwa Władysława Bułki, znajdujemy następującą definicję FUGI: 'szczelina w desce, np. w goncie' (Bułka 2009, 69).

W tym przypadku definicja sugeruje, że fuga to pęknięcie, rysa w desce, gdy tymczasem chodzi tu o celowo wycięty rowek w bocznej krawędzi gonta, w który wchodzi ostra, trójkątna krawędź następnego gonta. Tak powstaje połączenie wzdłużne gontów. Fuga wycinana jest ręcznie za pomocą fugu lub maszynowo za pomocą frezów na gonciarce (zob. fot. 3 i 4).

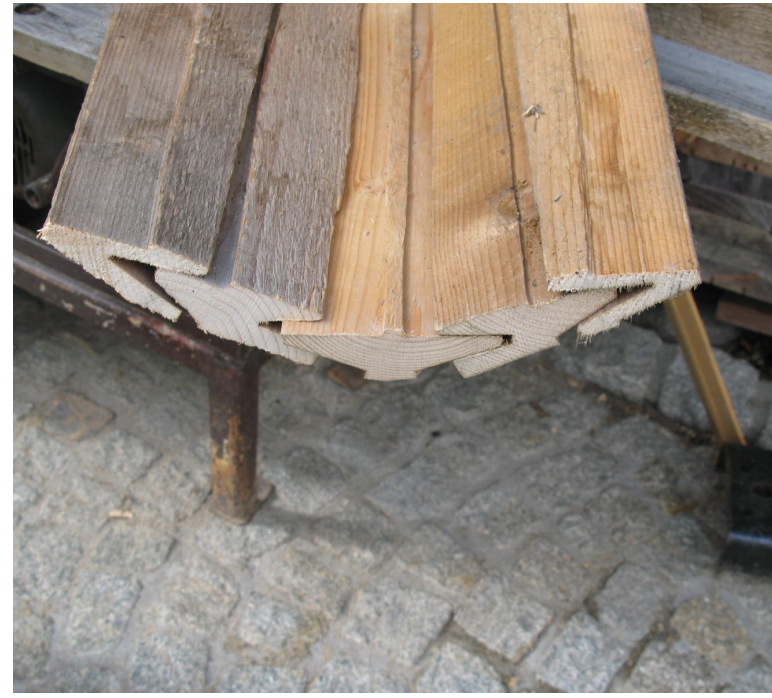

Fot. 3. Fugi w różnych typach gontów

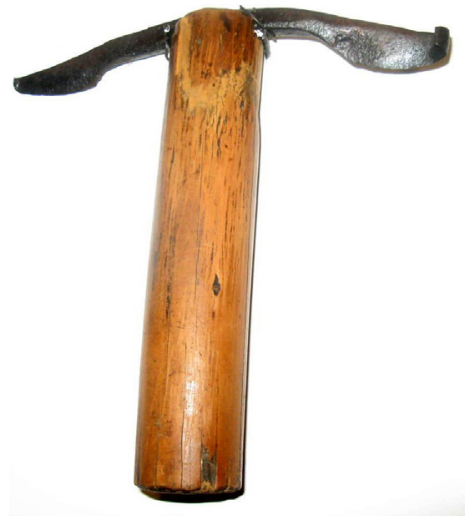

Fot. 4. Fug

Kolejny przykład jeszcze dobitniej pokazuje konieczność uzupełniania definicji ilustracją. To BEZMIAN. W Stowniku gwar polskich podana jest jego definicja: 'rodzaj prymitywnej wagi, składającej się z poziomego drąga z podziałką i ciężarkiem' (SGP 1983, II, 88). Definicja ta została powtórzona bez żadnej zmiany w Małym stowniku gwar polskich (MSGP, 20). Co ciekawe, definicja przezmianu, synonimu omawianego wyrazu jest jeszcze prostsza, a tym samym bardziej ogólnikowa. Przezmian to 'prymitywna waga' (MSGP, 225). Na podstawie takich definicji nie można sobie wyobrazić bezmianu. Brak w niej także istotnej informacji o tym, że jest to waga wisząca, a nie stojąca. Poza tym drag, który w rzeczywistości ma ok. 1,5 cm średnicy, nie jest zaiste drągiem. Niepoprawność takich definicji unaocznia ilustracja tejże wagi (fot. 5).

\section{Ilustracja jako weryfikacja ustaleń etnograficznych.}

Ilustracje mogą nawet pomóc zweryfikować prawidłowość ułożenia względem siebie elementów składowych urządzeń. Zdarza się to na przykład na ekspozycjach etnograficznych, jak choćby na przedstawionej poniżej parze zdjęć. Na zdjęciach pokazano prawidłowy (fot. 6.) i nieprawidłowy (fot. 7.) przebieg urobku tkackiego względem 


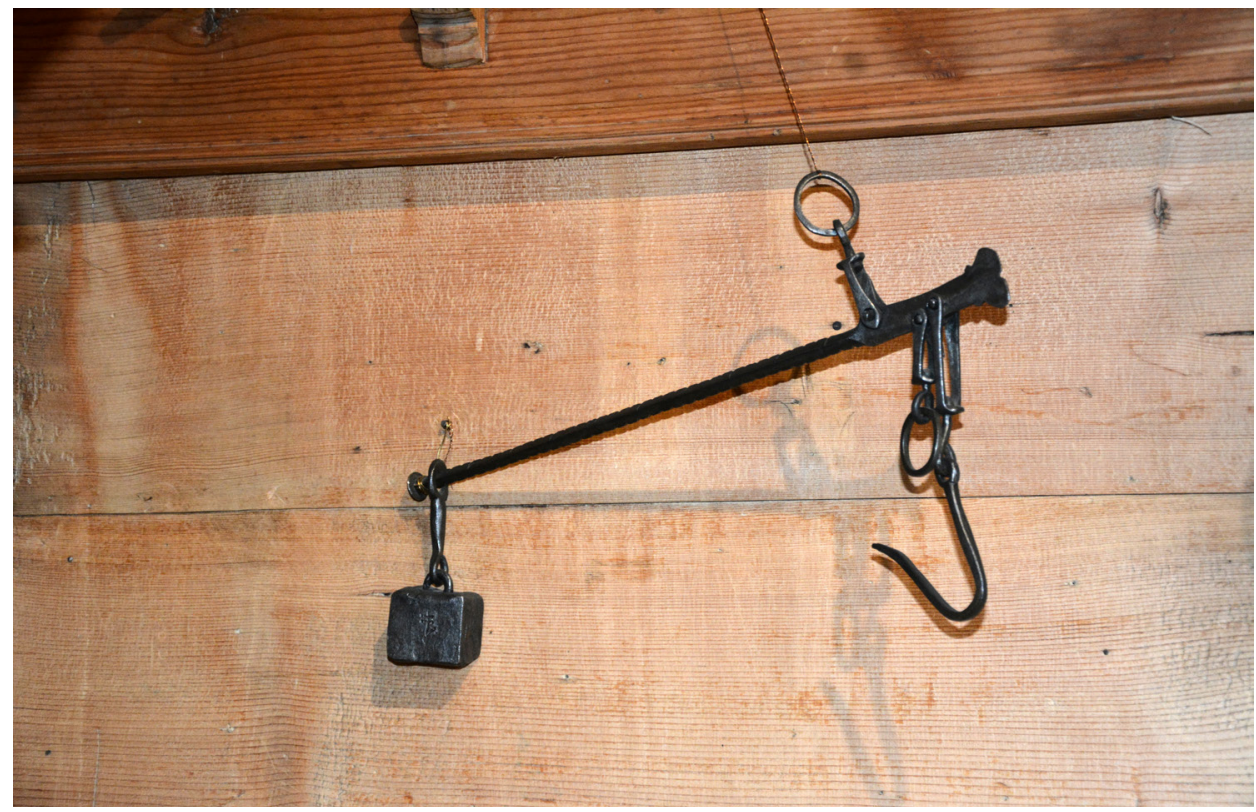

Fot. 5. Bezmian

tzw. grzadki (w terminologii podhalańskiej). Grządka to niezbyt masywna beleczka w warsztacie tkackim (na zdjęciach wskazano ją strzałką), wzmacniająca po pierwsze jego konstrukcję, a po drugie służąca do tego, by po niej (nie pod nią!) przesuwało się np. tkane płótno, nawijane następnie na wał. Na zdjęciu nr 7. wyraźnie widać, że tkacz miałby trudności ze zmieszczeniem kolan pod pasem płótna.

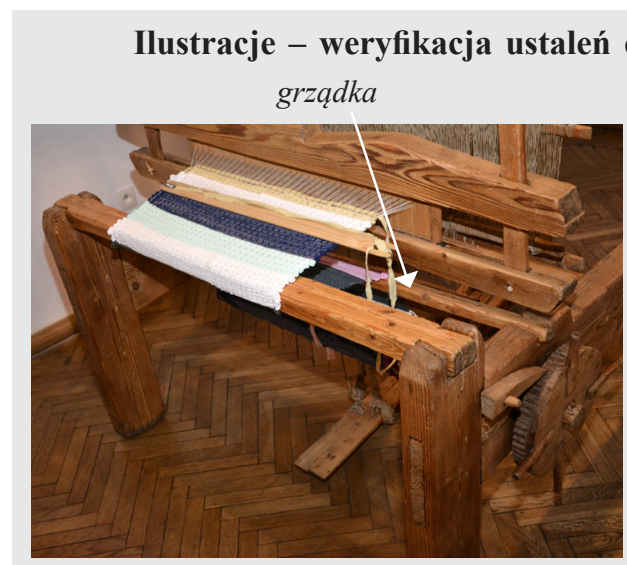

Muzeum Etnograficzne w Krakowie

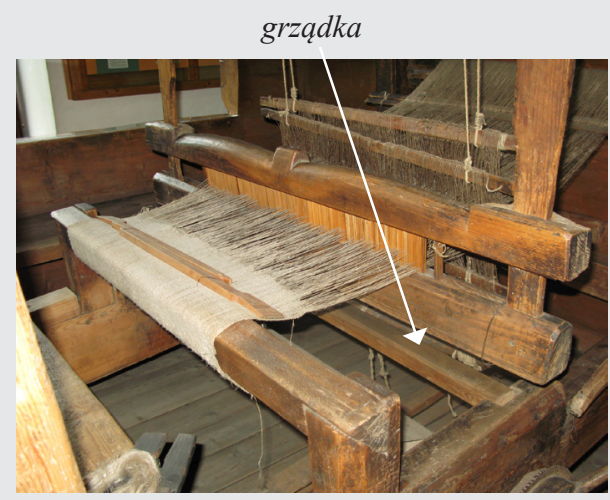

Muzeum Tatrzańskie w Zakopanem

Fot. 6. Warsztat tkacki

Fot. 7. Warsztat tkacki 
Ilustracja obrazująca specyfikę etnograficzną. Ilustracje unaoczniają też różnorodność etnograficzną artefaktów przy ich tożsamości funkcjonalnej. Czytelnikowi daje to możliwość poznania specyfiki kultury innych społeczności, a tym samym uświadomienia sobie swojskości kultury własnej. Sprawdza się to zwłaszcza w przypadku poznawania świata przez młodzież szkolną. Spośród wielu przykładów ilustrujących ten problem wybierzmy jeden - rączkę mocowaną w (na) kosisku - ta sama funkcja, zupełnie inna konstrukcja.

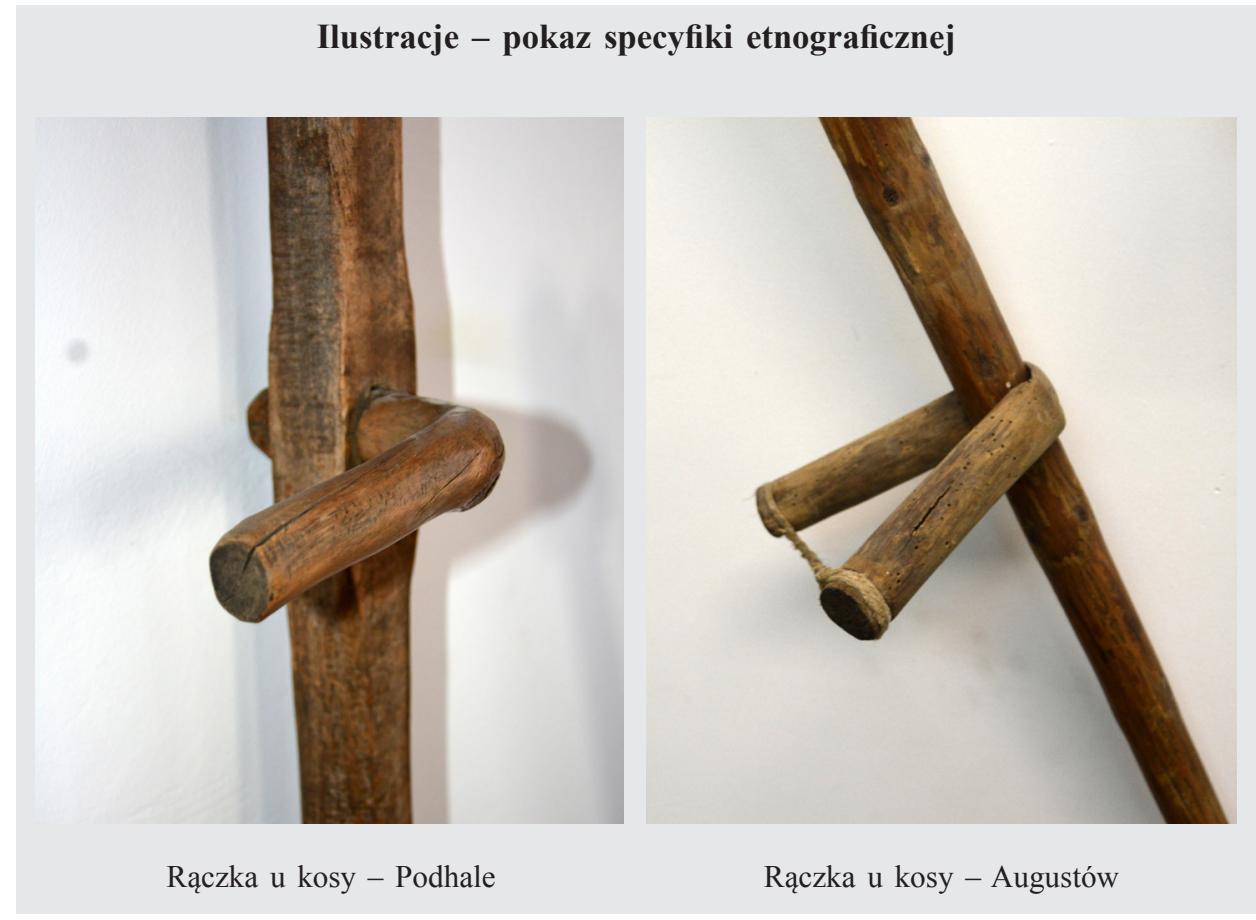

Fot. 8. Kosisko

Fot. 9. Kosisko

Ilustracja jako uzupełnienie opisu etnologicznego. Współpraca językoznawcy i etnografa jest oczywistą koniecznością. Wszak kultura ze swoim bogactwem, różnorodnością, wariantywnością etnograficzną żyje w słowie. Słowo sankcjonuje przejaw kultury, stabilizuje jego formę i treść. Przykładem może tu być termin góralskie róze ozdobny motyw tkany na kilimie. Jak mie kto pyto, coby mu zrobić góralskie róze, to jo juz wiym, o co mu chodzi - mówi kobieta tkająca kilimy. Jest to zatem wzór o określonym układzie elementów i o ich kolorystyce.

Porównując opracowania dialektologiczne i etnograficzne, zauważa się znaczącą różnicę w traktowaniu gwarowego (lokalnego) nazewnictwa opisywanych pojęć. Językoznawcę interesuje głównie skompletowanie wszystkich semów tworzących znaczenie pojęcia, natomiast etnograf skupia się na kształcie, materiale, wymiarach itp. Najbardziej widoczne jest jednak ignorowanie nazewnictwa szczegółowych 


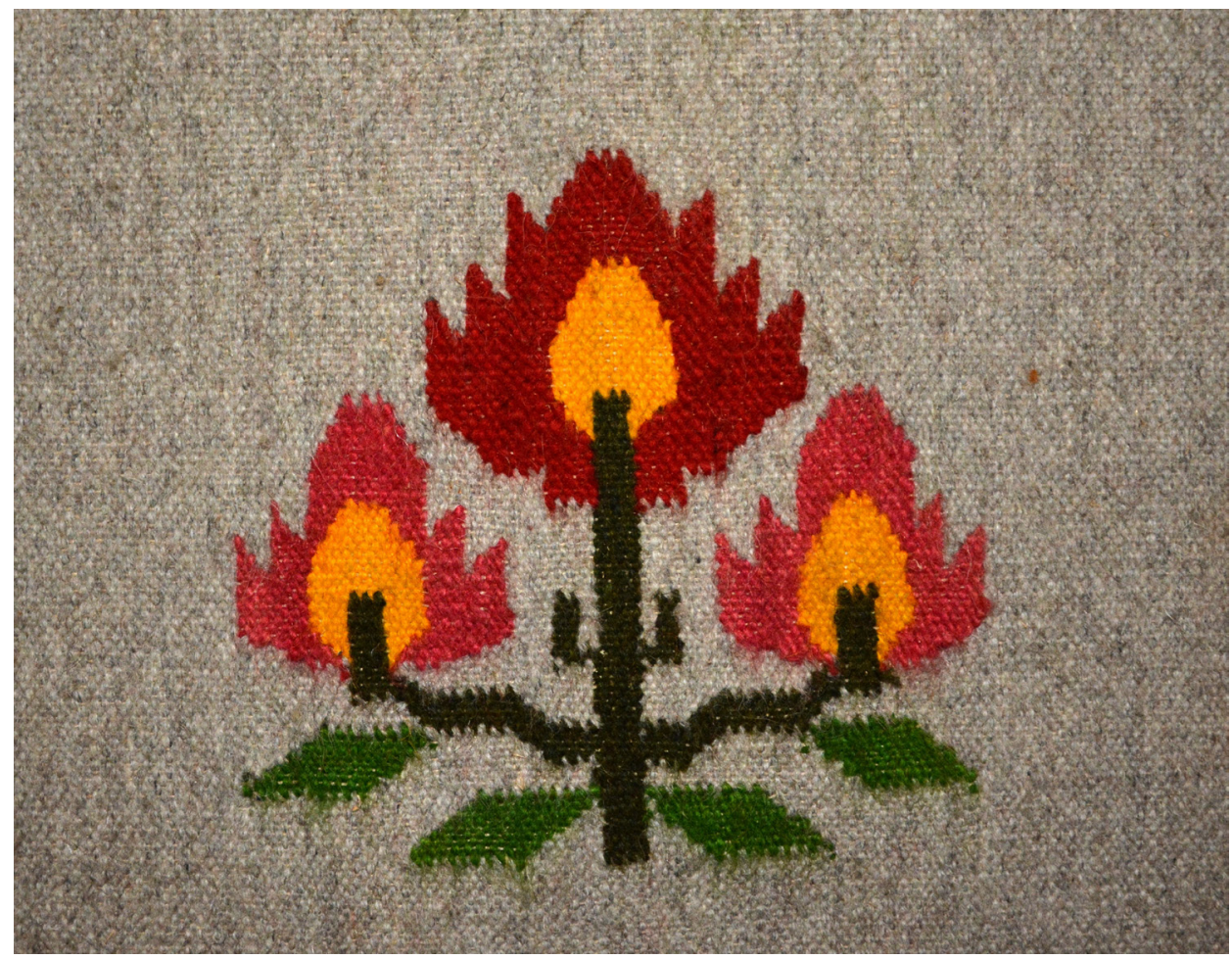

Fot. 10. Góralskie róze

elementów składających się na większą całość. Przekonują o tym choćby kolejne tomy z serii Atlas Polskich Strojów Ludowych z terenu Podtatrza - Orawy (Starek 1966), Podhala (Trebunia-Staszel, Etynkowscy, Fiedler 2015) i Spiszu (Starek 1954). Niezrozumiałym dla mnie jest pomijanie $w$ tych publikacjach wspomnianych wyżej szczegółów. Dla poparcia tego stwierdzenia wystarczy porównać choćby opis parzenicy lub zdobienie białej cuchy w stroju podhalańskim (Trebunia-Staszel, Etynkowscy, Fiedler 2015, 157-160). Opis etnograficzny zawiera jedynie najważniejsze, najbardziej widoczne elementy, pomija natomiast szczegóły (opis dialektologiczny zob. Ką́s 2018, VIII, 636; por. też inne wzory parzenic do s. 639). A przecież w zdobnictwie strojów ludowych swoje nazwy mają nawet poszczególne ściegi, wzory hafciarskie itd. To dla mnie trudne do zrozumienia postępowanie metodologiczne, ponieważ, logicznie wnioskując, etnografia ignoruje własny materiał badawczy. Można by zapytać: gdzież, jeśli nie w APSL, można oczekiwać szczegółowego opisu stroju ludowego?

Braki szczegółowego nazewnictwa rekompensują natomiast liczne ilustracje z dawniejszych i współczesnych czasów. Na tym tle szczególnie korzystnie wyróżnia się seria 10 tomów pt. Krakowiacy, Lachy, Górale. Stroje wsi małopolskiej (Brylak-Załuska 2020), wydana przez Małopolskie Centrum Kultury w Nowym Sączu. 
a - rozeta (tu: rozeta petna) [cyrhlica; gwiozda; rózyca; słonko; zbójeckie kółko; zbójecko gwiozda]

$\mathrm{b}$ - piyłka

c - kotwica [dusa]

$\mathrm{d}-$ poncek

e - krzesiwko

f - dziub ['śpic]

g - miyrwa

h - kohut

i - kula

$\mathrm{j}$ - dziewiynciornik [dziewiynciosiył; dziewiynćsiył]

$\mathrm{k}$ - głowa

1 - przipór [ozpór]

1 - pazdurek [łapka; rapka]

$\mathrm{m}$ - piórko

$\mathrm{n}$ - ślimocek [piesek]

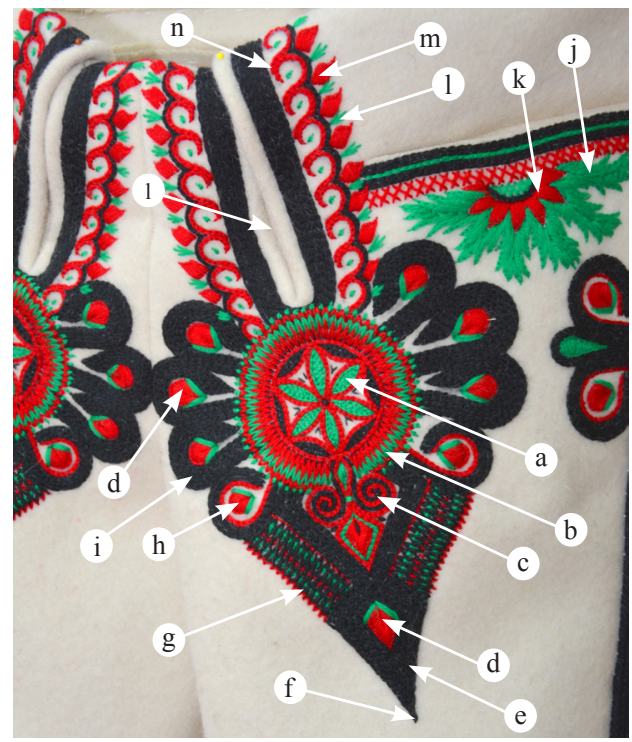

Fot. 11. Parzynica ${ }^{2}$

a - grzynda (utworzona z kręgu KWIOTECKÓW) [ogródek; wionek]

b - kula

c - poncek

$\mathrm{d}$ - listek

e - prysc

f - krzesiwko

$\mathrm{g}-$ dziub

$\mathrm{h}-$ poncek

i - miyrwa

$\mathrm{j}$ - dusa

$\mathrm{k}$ - kotwica [dusa]

1 - kwiotecek

1 - środek

$\mathrm{m}$ - piyłka

$\mathrm{n}$ - stebnówka

o - dyga

p - przipór

r - krokiewka

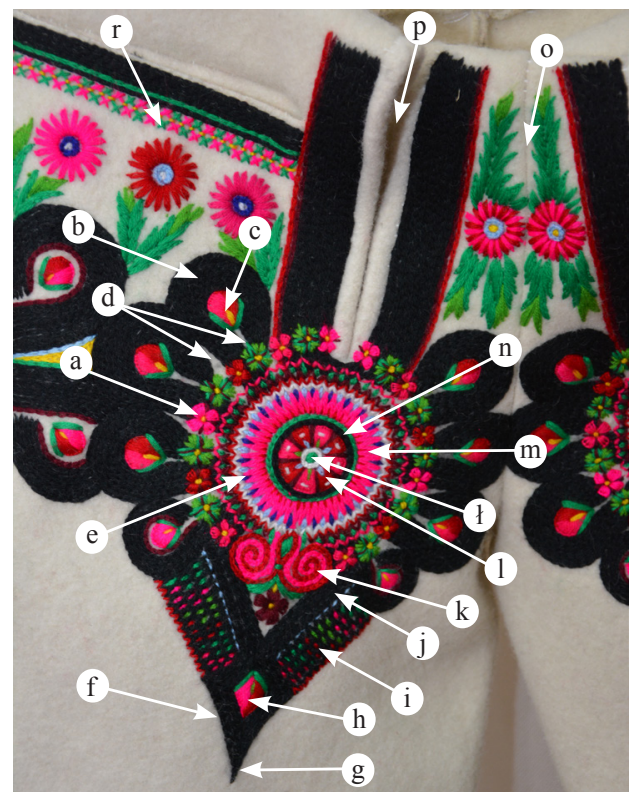

Fot. 12. Parzynica z grzynda

${ }^{2} \mathrm{~W}$ opisie elementów składowych parzynicy podaję tylko ich nazwy wraz z synonimami, natomiast nie podaję nazw miejscowości, w których one są używane. Pełną informację zawiera Ilustrowany leksykon gwary i kultury podhalańskiej (Kąś 2015-2019). Taką zasadę stosuję też w przypadku innych ilustracji. 
Ilustracja obrazująca relacje między elementami składowymi; też: relację holonim (całość): meronim (część). To ostatnia $\mathrm{z}$ omawianych tu funkcji ilustracji w słowniku gwarowym. Wskazuję tu na nią, by uzmysłowić banalną prawdę, że definicje typu „część konstrukcyjna wozu”, „element zdobienia odświętnego serdaka” itp. nie przynoszą chluby autorowi, a i czytelnika też nie mogą zadowolić. Jeśli zatem sama definicja pozostawia sporo do życzenia, to przynajmniej ilustracja może okazać się informacyjna. Staje się to dzięki unaocznianiu relacji przestrzennych między elementami składowymi przedstawianego obiektu. Por. ilustrację gęśli (skrzypiec) ze szczegółami konstrukcyjnymi i ich nazwami gwarowymi (podhalańskimi).
a - główka
$\mathrm{b}-$ dyga
c - sýjka
d - góra [deka górno; wiyrch]
e - podstawek [podstawka]
f - głośnica [ef; esica; eska; głosówka; głośnik; hef; heso]
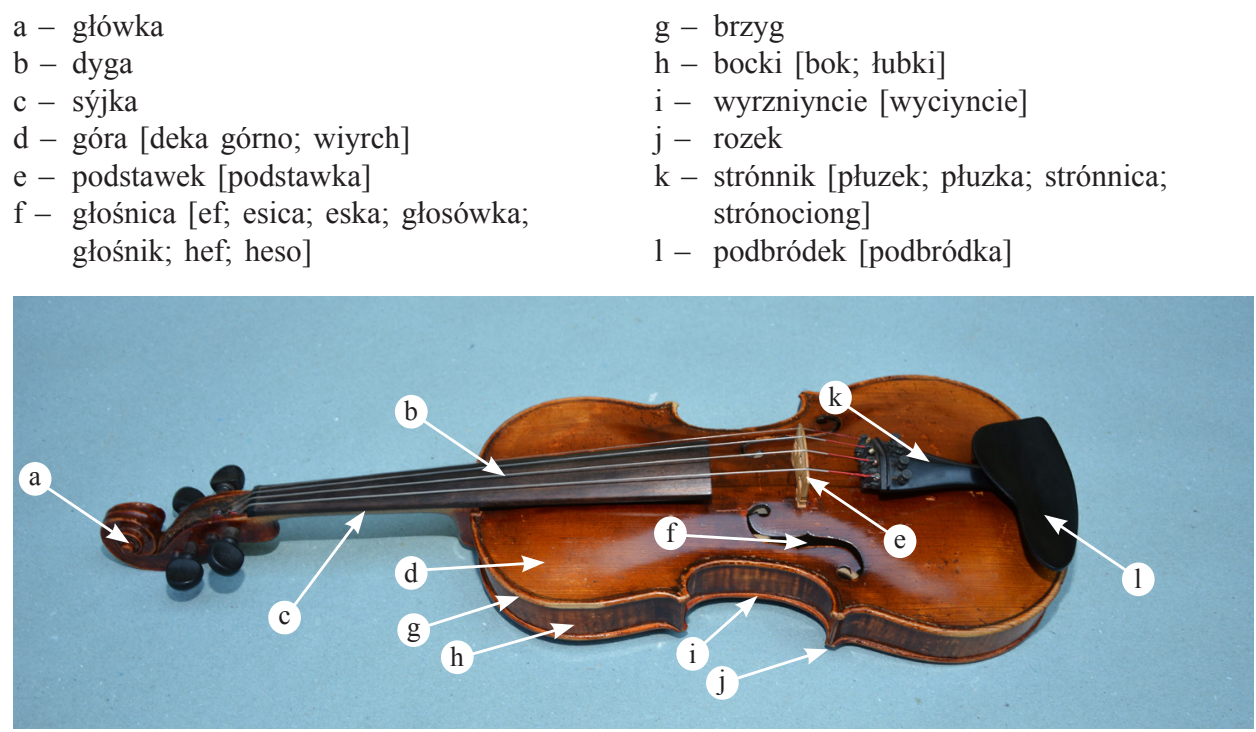

Fot. 13. Gynśle

Przedstawione w niniejszym tekście rozważania nie zamykają dyskusji nad sposobami uprzystępniania treści przyjęzykowych w słownikach gwarowych za pomocą ilustracji. Bezsprzeczną okazuje się konieczność uzupełniania opisu językowego o elementy ikonograficzne. Podkreślę jeszcze raz: to nie kwestia atrakcyjności publikacji. To kwestia informacyjności współczesnego słownika gwarowego. Ograniczanie się dziś do samego opisu słownego powoduje ograniczenie kręgu odbiorców do grupy specjalistów językoznawców. Nowy typ czytelnika wymusza zmiany warsztatu leksykograficznego. Z przyjemnością wypada mi odnotować, że w ostatnim okresie w coraz większej ilości słowników gwarowych ilustracje traktowane są jako oczywiste uzupełnienie treści wyrażanych słownie. Potwierdzają to wydawane ostatnio słowniki (Jurczyk 2009; Kurzeja 2012; Pelcowa 2012; Szewczyk 2014; Łomnicka-Dulak 2018; Kobus, Stępień 2018; Osowski 2018; Sierociuk 2019; Karaś 2020). Można tylko mieć nadzieję, że w kolejnych słownikach gwarowych ilustracjami będą uzupełniane wszystkie hasła z zakresu kultury materialnej, a nie tylko wybrane. Autorzy słownika spisko-wielkopolskiego Co 
a - policek

b - podsýjnik [podbródek; podgarle]

c - lusterko

d - nogłówek e - nocółek [nacółek]

f - łańcusek

g - nachrapnik

h - kryg [munśtuk]

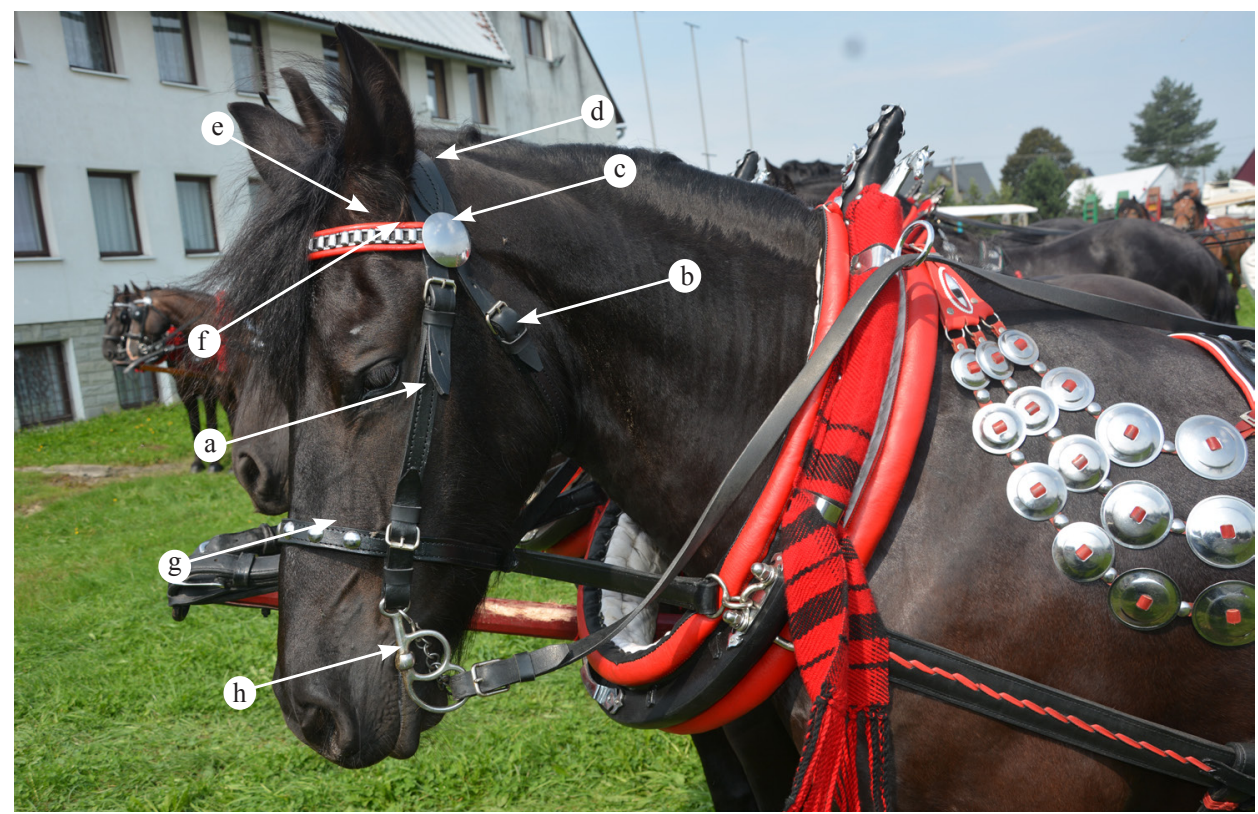

Fot. 14. Huzda siuto

wieś, to inna pieśń... (Co wieś 2014) poszli jeszcze dalej, dodając do tekstu nie tylko zdjęcia, ale też płytę CD z nagranymi wybranymi pracami charakterystycznymi dla kultury wiejskiej, np. pieczeniem chleba, żniwami itp. W ten sposób ikonografia w słowniku gwarowym została podniesiona na jeszcze wyższy poziom, wyznaczając tym nowy standard w leksykografii gwarowej. To jak najbardziej uzasadniona nowość, ponieważ ani opis, ani statyczny obraz nie są w stanie oddać charakteru niektórych czynności. Film daje nowe możliwości dokumentowania wiejskiej kultury materialnej. I tak oto, przy wykorzystaniu nowych możliwości technologicznych dialektologia na powrót brata się z etnografią. Wszak kultura, nie tylko wiejska, jest niepodzielna.

\section{Literatura}

Brylak-Załuska M. (red.) (2020), Krakowiacy, Lachy, Górale. Stroje wsi małopolskiej, t. I-X, Nowy Sącz.

Bułka W. (2009), Mały stownik gwary góralskiej z Rycerki Górnej, Bielsko-Biała.

Co wieś (2014), Co wieś, to inna pieśń. Stownik gwary Bukówca Górnego w Wielkopolsce i regionu Spisza w Małopolsce, (praca zbiorowa), Kraków. 
Jost H. (1987), Słownik gwarowych wyrazów technicznych z terenu Podtatrza, Nowy Sącz.

Jurczyk I. (2009), Stownik gwary wsi Wola Radziszowska, Wola Radziszowska.

Karaś H. (2020), Gwara Bugaja na Pogórzu (gm. Biecz, pow. Gorlice), Warszawa.

Kawalec J. (1964), Tańczący jastrząb, Warszawa.

Kąś J. (2003), Etnografia w słowniku gwarowym, [w:] Gwary Dziś, t. 2. Regionalne stowniki $i$ atlasy gwarowe, red. J. Sierociuk, Poznań, s. 239-246.

Kąś J. (2003), Stownik gwary orawskiej, Kraków [II wyd. 2011].

Kąś J. (2015-2019), Ilustrowany leksykon gwary i kultury podhalańskiej, Bukowina TatrzańskaKraków-Nowy Sącz.

Kąś J. (2017), Dlaczego ilustrowany leksykon gwary i kultury..., a nie stownik gwary...?, [w:] Діалекти в синхронії та діахронії. Трансформація діалектного континууму і проблеми лінгвоекологіï, Kijów, s. 144-157.

Kobus J., Stępień M. (red.) (2018), Słownik języka mieszkańców okolic Czerniejewa. Praca na roli $i$ w gospodarstwie, Poznań 2018.

Kucała M. (1957), Porównawczy słownik trzech wsi małopolskich, Wrocław.

Kurzeja M. (2012), Stownik gwary górali łąckich, Łącko.

Łomnicka-Dulak W. (2018), Nadpopradzka dawność. Gwara i kultura górali z okolic Piwnicznej, Piwniczna-Zdrój-Nowy Sącz.

MSGP (2009), Mały stownik gwar polskich, red. J. Wronicz, Kraków.

Osowski B. (red.) (2018), Gospodyni. Stownik języka mieszkańców powiatu kolskiego, Poznań.

Osowski B. (red.) (2018), Gospodarz. Słownik języka mieszkańców powiatu kolskiego, Poznań.

Pelcowa H. (2012-), Stownik gwar Lubelszczyzny, Lublin.

SGP, Słownik gwar polskich, red. M. Karaś (Źródła, z. 1-2), J. Reichan (z. 3-15), J. Okoniowa (z. 16-27), R. Kucharzyk (z. 28-), Kraków 1977-.

Sierociuk J. (red.) (2019), Słownik języka mieszkańców ziemi tukowskiej, Praca na roli $i w$ gospodarstwie. Poznań.

Starek E. (1954), Strój spiski, Atlas Polskich Strojów Ludowych, cz. V: Małopolska, z. 15, Wrocław.

Starek E. (1966), Strój orawski, Atlas Polskich Strojów Ludowych, cz. V: Małopolska, z. 11, Wrocław.

Szewczyk Z. (2014), Stownik gwary Lachów Sadeckich, Podegrodzie.

Trebunia-Staszel S., Etynkowscy A. i M., Fiedler K. (2015), Strój podhalański, Atlas Polskich Strojów Ludowych, cz. V: Małopolska, z. 18, Wrocław. 